\title{
Greimas'ın Göstergebilim Yöntemiyle Bir Filmi Okumak: Milcho Manchevski ve Yağmurdan Önce
}

\author{
Banu ÇAKMAK DUMAN*
}

Özet

Bir sanat yapıtında yaratıcı genellikle okuru/izleyiciyi belirli anlam ya da duygular etrafında buluşturmak ister. Bu nedenle belirli dilsel ve görsel öğeleri harekete geçirir. Sanat yapıtında bu öğeler genellikle göstergelerdir. Yaşam da onu konu alan sanat da göstergelerden oluştuğu için bunu inceleyen bir bilim doğmuştur: göstergebilim. Okuyucu/izleyici göstergeleri yapıtın bağlamı içinde, birbiriyle ilişkili olarak, göstergebilim yöntemi yardımıyla adım adım çözümlediğinde söz konusu anlama ulaşabilir. Bu yazıda bu tür bir göstergebilimsel okuma modeli Milcho Manchevski’nin filmi Yağmurdan Önce üzerinden gösterilmeye çalışılmış, alımlayıcının yapıtla aktif ilişki kurduğu bir anlamlama biçimi sunulmuştur. Bunun için film Greimas'ın göstergebilim yöntemiyle çözümlenmiştir.

Anahtar Sözcükler: Gösterge, Anlam, Göstergebilim, Film, Milcho Manchevski, Yağmurdan Önce

\section{Reading A Film Semeiologically: Milcho Manchevski And Before The Rain}

\section{Abstract}

A creator of an artwork usually wants to bring the reader / viewer together around a specific meaning or feelings. Therefore, the artist activates specific linguistic and visual elements. These elements are often indicators in the work of art. Because of the life and the artwork which is about life, consist of indicators, a discipline has arised which analyses the indictors: semeiology. As soon as the reader / viewer analyses indicators within the context of artwork, related to each other step by step, semeiologically, he/she can figure out the intended meaning. The semeiotical reading model has been illustrated in this article about the film Yagmurdan Once by Milcho Manchevski and it presents a form of an established ongoing relationship of reader/viewer with works of art. Hence the film is analysed by semeiotical method of Greimas.

Keywords: Indicator, Meaning, Semeiology, Film, Micho Mancevski, Before the Rain 


\section{Giriş}

Sanatsal süreçte yapıt aracılığıyla sanatçı ve alımlayıcı arasında yaşanan bir tür anlam, duygu alışverişidir. Belirli anlamları, duyguları estetik yollarla ete kemiğe büründürerek okuyucuyla buluşturmak isteyen hemen her sanatçı, bunun için anlatı ya da öykü kavramının bir tarafına tutunur. Söz konusu olan sanat eseri bir sinema filmi olduğunda anlatı ya da öykünün yanına bir de görüntü eklenir. Sinema anlatıyı görsel malzemeyle birleştirerek veren, daha açık bir deyişle anlama, görüntüler aracılığıyla akan bir öykünün altında yaşam veren bir sanat dalıdır. Şu halde sinema filmi hayatımızdaki pek çok şey gibi başlı başına bir göstergedir çünkü görünen ve anlatılanın ötesinde bir anlamın hizmetindedir. Bu durum gösterge kavramının başat özelliğiyle örtüşür: gösterge işlev açısından hep anlam aktarma özelliği taşır, göstergeler de anlam aktaran araçlardır (Guiraud, 1999: 9). Böylece anlamın taşıyıcısı olan sinema filmi bütün olarak bir gösterge kabul edilmelidir.

Gösterge gösteren ve gösterilen ayrımından oluşur. Örneğin sözcükler bir şeye işaret ettikleri için birer göstergedirler ve bir göstergenin iki yönü vardır: biri ses imgesidir ki gösteren adını alır, biri kavramdır ki gösterilen adını alır; köpek dediğimizde ağzımızdan çıkan söz gösteren, bunun işaret ettiği, kafamızda canlanan kavramsa gösterilendir (Moran, 2006: 188). Aynı şekilde bir gösterge olarak sinema filmine bakılacak olursa, filmin yüzeyinde bulunan görsel malzeme ve anlatı, sinema filmi göstergesinin gösteren kutbuna, filmdeki gösterenin altında yatan anlam ya da anlatılmak istenen düşünceler ise gösterilen kutbuna denk düşer. "Sözcüğün en geniş anlamıyla gösterge, bir başka şeyin yerini almasını sağlayan özellikler taşıdığından kendi dışında bir nesne, olgu, varlık belirtebilen öğedir" (Vardar, 2001: 72). Burada da film sadece estetik bir görüntüler bütünü ya da öylesine bir öykü yani yalnızca yüzeyde görünenlerden ibaret değildir. Gösteren kutbundakiler belirli bir amaçla bir araya geldiği ve kendisinden öte, derinde yatan gösterilene yani başka bir anlama hizmet ettiği için sinema filmi bütün olarak gösteren ve gösterilenden oluşan bir gösterge olmaktadır.

Dilden görüntülere, toplumsal kurallardan anlatılara, davranış biçimlerine, giyim kuşamdan sanat eserlerine değin dört bir yanımız göstergelerle kuşatılmıştır. Aslında genelde sanat eseri özelde sinema filmi hayatımızı kaplayan göstergelerden yalnızca biridir. Bu nedenle bu çok sayıda göstergeyi incelemek için göstergebilim adlı özel bir alan doğmuştur. "Göstergebilim, göstergeler evrenine özgü yasaları belirlemeyi, işleyiş kurallarını saptamayı, inceleme yöntemlerini oluşturmayı, betimleme ve açıklama işlemlerini gerçekleştirmeyi amaçlar” (Vardar, 2001: 84-85). Bir başka deyişle belirli yöntemler aracılığıyla gösterenden hareketle gösterilene ulaşmak, göstergenin anlamla bağıntısını çözümlemekte geçerli metotları her türlü göstergeye uygulamak bu bilimin temel amacıdır.

\section{Algirden Julien Greimas'ın Göstergebilimsel Yaklaşımı Hakkında}

Oldukça güncel bir alan olan göstergebilim üzerine çalışmalar yapan pek çok isim, buna bağlı olarak bu isimlerle özdeşleşen türlü yöntemler vardır. Viladimir Propp, Ferdinand de Saussure, Umberto Eco, Roland Barthes bu isimlerden yalnızca birkaçıdır. Kuşkusuz her bir ismin konuya yaklaşımı ve alana katkısı çok değerlidir. Ne var ki gerek çağdaş göstergebilimde birincil bir rol oynaması gerekse göstergebilim içerisinde anlam olgusuna merkezi önem vermesi ve yöntemini anlam arayışına temellendirmesi Greimas'ın ayrı bir yere koyulmasına neden olur. Ona göre göstergebilim hem anlamlamanın oluşum ve kavranım koşulları üzerine genel bir düşünce hem de anlamlı nesnelerin somut çözümlemelerinde uygulanacak bir yöntemler bütünü olarak bağımsız bir bilim dalı olmaya yönelmiştir (Greimas \& Landowski, 1979: 5).

Buradan hareketle bir bilim dalı olarak göstergebilimin, anlam ararken yol gösterici olacak bilimsel bir yöntem barındırması gerekliliği gündeme gelir. Greimas'ın bir başka önemli yönü de bu amaçla tutarlı, kapsamlı, analitik, matematiksel bir yöntem geliştirmiş olmasıdır. Greimasçı göstergebilim hem anlamlama üzerine genel bir düşünce hem de anlamlı nesneleri çözümleme yolunda bir yöntemler bütünü olmaya yönelmiştir; bu göstergebilimin amacı bir üst bilim olmaktır (Yücel, 2005: 128). Bu üst bilimin kendine özgü bir yöntemi ve kendine ait bilimsel bir üst 
dili vardır. Burada bu üst dilden biraz söz etmekte fayda vardır. Öncelikle Greimas göstergebiliminin uygulanacağı malzeme daima anlam barındıran bir anlatı içerir. Greimas bu anlatılara anlatı izlencesi adını verir. Anlatıcı izlencesi bir özne tarafından gerçekleştirilen ve bir başka özneyi etkileyen bir durum değişimidir (Greimas \& Courtes, 1979: 297). Anlatı izlencesine yönelik yapılan tespitlerin somut ve bilimsel bir şekilde şemalandırılması sırasında kullanılan başlıca işaretler şunlardır: "Aİ: Anlatı İzlencesi, Ö: Özne, N: Nesne, U: Bağlaşma, Birleşme, $\cap$ : Ayrışma, $\rightarrow$ : Dönüşüm”" (Yücel, 2005: 152). Görüldüğü gibi Greimas, kendine özgü bir dil, işaretler sistemi barındıran bir yöntem inşa etmiştir.

Anlamı temel alması ve onu arama yöntemi sunması nedeniyle Greimas göstergebiliminin başlangıç noktası yazınsal alandır yani yazılı eserlerin anlamına ulaşma ve onları çözümlemede bu yöntem verimli bir kaynak niteliğindedir. Bununla birlikte yöntem bugün yalnızca yazınsal alanla sınırlı değildir. Greimas göstergebilimi kendi kendine yeten, özerk bir bilimsel tasarı olarak ortaya atılmış, Paris Göstergebilim Okulu aracılığıyla bu tasarı değişik alanlara yönelik uygulamalarla geliştirilmiştir. Bu çalışmalar aracılığıyla bugün insanın davranışlarının, tutkularının, yaratılarının göstergebiliminden söz edilebilmektedir (Rıfat, 2005: 140). Dolayısıyla Greimas göstergebiliminin bir başka ayırıcı özelliği çok yönlü olması, bir tek alanla sınırlı kalmayıp geniş bir kapsama sahip olmasıdır. Zira temelinde anlam olduğu için yalnızca yazın değil, içinde anlam barındıran her şey Greimas göstergebilimiyle incelenebilir hatta hayatın kendisi bile... Anlam barındıran anlatı kalıpları Greimas göstergebiliminin temel malzemesidir ve bunlar hayatın her alanında karşımıza çıkar. Bu her anlatıda karşımıza çıkan bir kalıp, yalnızca her anlatı kahramanının izlediği yol değil, insan hayatının anlam arayışı olarak da yorumlanabilir (Greimas, Courtes, 1979: 10).

Anlam arayışına temellenmesi, bunun için somut, bilimsel bir yöntem önermesi ve çok yönlü bir kimliğe sahip olmasıyla bu yazıda odağa alınan Greimas göstergebilimi bütün bunların yanında bugün en çağdaş, güncel ve geçerli göstergebilimsel yaklaşımdır demek yanlış olmaz. Denilebilir ki Greimas'ın yöntemi göstergebilimin en tutarlı, en verimli ve en ileri aşamasını oluşturur (Yücel, 2005: 129). Bütün bu nedenlerden ötürü, bu yazıda türlü göstergebilim yaklaşımları içinden Greimas'ın yaklaşımı seçilmiş ve göstergebilimsel bir film çözümlemesi yapmak amacıyla yol gösterici olarak alınmıştır. Anlamın barınağı olan bir anlatıyı ve görüntüyü içeren bir sinema filmini incelerken Greimas göstergebiliminin aydınlatıcı olacağı düşünülmüştür. Çünkü bugün Greimas göstergebilimi anlamın değişik biçimlerde süslenmesine, giydirilmesine uzanan bütün aşamaları değerlendirmektedir (Rıfat, 2005: 201). Greimas göstergebiliminin anlama ulaşmada öne sürdüğü aşamalar, bilimsel yöntemin detayları ve işlevi, öne sürülen işaretler sisteminin kullanımı film çözümlemesi ilerledikçe somutluk kazanacaktır.

Bunun için Greimas'ın göstergebilimsel yönteminden hareketle bir gösterge olan sinema filminin çözümlemesi yapılmaya çalışılacak, A. Julien Greimas'ın ileri sürdüğü göstergebilim yöntemi, Milcho Mancevski'nin Yağmurdan Önce adı filminin analizi için kullanılacaktır. Söz konusu yöntem aracılığıyla, Milcho Mancevski'nin Yağmurdan Önce filminde örtük ya da açık olarak dile getirdiği anlamlar tespit edilip yorumlanacak, böylelikle hem filmin anlam evreni hem de Greimas göstergebiliminin uygulanış biçimi açıklığa kavuşacaktır.

\section{Yağmurdan Önce Filmine Dair}

Yönetmenin ilk uzun metraj filmi olan Yağmurdan Önce 1994 yılında çekilmiş, İngiltere, Fransa, Makedonya ortak yapımı dramatik bir savaş filmi olarak tanımlanır (Mancevski, 1994). Çok sayıda ödül kazanmış olan filmde Makedonlar ve Arnavutlar arasında yaşanan, dini inanç farklılığından kaynaklanan savaş konu edilir. Film 1990 yıllarında Makedonya ve Londra'da geçer. Üç ayrı epizottan oluşan filmde birinci ve ikinci epizotta anlatılan öyküler üçüncü epizotta birbirine bağlanır.

Birinci epizotta Kiril ve Zamira'nın öyküsü konu edilir. Vaftiz günü yaklaşan Kiril, bir akşam kiliseden döndügünnde Zamira adlı bir Arnavut kızı odasına sığınmış olarak bulur. Onu bir Makedon'un ölümüne neden olduğu suçlamasıyla öldürmeye gelen kişilerden saklar. Tanrı için ettiği 
suskunluk yeminini de bozar, günah işlemiş olur. Birbirini seven iki genç kaçmaya kalkarlar ancak bu defa Zamira'nın ağabeyi Ali ve dedesi Zekir onları bulur, bir Hıristiyan'la kaçtığı için dedesi Zamira'yı döver. Zamira birbirlerini sevdiklerini söylemeye çalışır, dedesi Kiril'in ona olan sevgisini sınamak için Kiril'in gitmesine müsaade eder. Hiçbir şey anlamayan Kiril yürümeye başlar, Kiril'in arkasından koşan Zamira ise ağabeyi Ali tarafından vurulur.

İkinci epizotta Kiril'in Zamira ile beraber yanına kaçmayı düşündüğü amcası, Pulitzer ödülü almış, kırk yaşlarındaki fotoğrafçı Aleksander Kirkov'un öyküsü anlatılır. Alex savaş fotoğrafları çekmek için iki haftalığına gittiği Bosna'dan döndüğünde çok değişmiştir. Çünkü orada iyi bir kare yakalayamadığından şikayet etmesi üzerine bir asker bir esiri öldürmüş, o da bunu fotoğraflamıştır. Bu nedenle vicdanı rahatsızdır. Şimdi savaşın yaşandığı memleketine dönmek, fotoğrafçılığı bırakmak istemektedir. Aynı ajansta çalıştığı evli sevgilisi Anne'ye bunu anlatır, onun da kendisiyle gelmesini ister. Anne bunu kabul etmez, hamiledir, ayrılırlar. Alex yola çıkar, Anne ise bir restoranda eşi Nick'e hamile olduğunu ama ondan ayrılmak istediğini söylemektedir. Bu sırada garsonla tartışan bir adam silahla restoranı tarar, Anne'ye bir şey olmaz ancak Nick yüzü parçalanarak ölür.

Üçüncü epizotta Makedonya'ya dönen Alex yeğeni Kiril'in vaftiz törenine katılacaktır. Dolayısıyla ikinci ve üçüncü epizot birinci epizodun öncesi gibi görünür ancak araya giren sahneler zamanı tam olarak algılamamızı engeller, sıçramalar vardır. Alex kuzenleri ve akrabalarıyla güzel vakit geçirir, yaşadıklarını Anne’ye yazar, fotoğraf makinesini yalnız aile fotoğrafı çekmek için eline alır. Eski aşkı Hanna'yı çok değişmiş bulur. Hanna birinci epizotta ölen Zamira'nın annesidir. Bir gün Alex'in kuzeni Bojan ölür, Bojan'ın yanında en son görülen Zamira Arnavut olmasının da etkisiyle bu ölümden sorumlu tutulur. Alex’in diğer kuzenleri Zamira'yı yakalar, Hanna Alex’ten yardım ister çünkü Zamira aslında Alex’in kızıdır. Alex bunun üzerine kuzenlerinin elinden Zamira'yı alır, onu götürürken kuzeni Alex’i arkasından vurur, Zamira kaçar ve Kiril'in odasına sığınır, böylece film başladığı noktada son bulur.
Bu karmaşık olay örgüsü zengin bir görsel anlatımla birleşerek çok boyutlu bir anlam evreninin kapılarını aralamaktadır. Söz konusu anlamlara ulaşmak için film eşliğinde Greimas göstergebiliminin çeşitli aşamalarından geçmek aydınlatıcı olacaktır. Bu aşamalardan ilki yüzey yapı ikincisi ise derin yapı adını taşımaktadır.

\section{Yağmurdan Önce Filminin Göstergebilimsel Çözümlemesi}

\section{1. Yağmurdan Önce Filminde Yüzey Yapı}

Yüzey yapı adından da anlaşıldığı gibi eserde ilk anda ele gelen, yüzeydeki verileri içerir. Amaç yüzeydeki bu verileri takip ederek derindeki anlama ulaşmaktır. Zira anlam yüzey yapıda bulunan kişiler, olaylar, nesneler, görüntüler gibi unsurların ardına itinayla gizlenmiştir. "Göstergebilim anlamlamanın temel yapılarından anlamın değişik biçimlerde süslenmesi, giydirilmesi olan söylemsel, betisel düzeylere kadar olan bütün aşamaları değerlendirir" (Rıfat, 1990: 129). Şu halde yüzey yapının içinde iki aşama ile daha karşılaşılmaktadır: söylemsel ya da anlatısal düzey ile betisel ya da figüratif düzey. Anlatısal katmanda bir dönüşüm, dönüşümün içerdiği eylemler ve dönüşüm sürecindeki eyleyenler ele alınır. Betisel katmanda ise bu dönüşüm ve eyleyenlerin betisel içerikleri ve eyleyenlerin üstlendikleri roller incelenir (Kıran, 2000: 130-131). Tekrar açık şekilde ifade etmek gerekirse, anlatısal düzey kişileri, olayları, öyküyü; betisel düzey kişilerin, nesnelerin, görüntülerin anlama hizmet eden detaylarını içerir, derin yapıya geçiş aşamasını oluşturur. Ancak bütünde bu iki düzey de yüzey yapıya aittir ve eğer film bir gösterge ise, yüzey yapıda yer alan bu verileri derin yapıdaki anlamı saklı tutan gösteren kutbu olarak düşünmek duruma somutluk kazandırır. Özetle burada göstergebilimde çizilen yüzeyden hareketle derine, gösterenden hareketle gösterilene, göstergeden hareketle anlama ulaşmanın yol haritası takip edilmektedir.

\section{1. 1. Anlatı Düzeyi}

Sinema filmini göstergebilimsel yöntemle incelemeyi olanaklı kılan en önemli özellik bir senaryo barındırmasıdır. Film senaryosu her şeyden önce sözlü olarak okun- 
ması gereken yazılı bir metindir (Öztokat, 2005: 25). $\mathrm{Bu}$ nitelik sinema filminin temelinde göstergebilimsel yöntemle çözümlenecek bir anlatı bulunduğu anlamına gelir. Greimas'a göre her anlatı başlangıç durumuyla bitiş durumu arasında bir geçiş, bir dönüşüm gerçekleştirir. $\mathrm{Bu}$ dönüşüm sürecinde eyleyenler değişik işlevler ya da roller üstlenirler. Eyleyenler bu iki uç arasında başka eyleyenleri dönüştürürken kendileri de değişir, dönüşür (Kıran, 2007: 301). Buna koşut olarak bir anlatı içeren filmde, çok sayıda eyleyen ve onların eylemleri doğrultusunda yaşanan dönüşüm söz konusudur. Anlatı düzeyini incelerken yapılacak olan, bunları filmdeki her bir epizot için ayrı ayrı belirlemek ve çözümlemek olacaktır. Böylece epizodik bir yapı ile kurgulanan filmin biçimine koşut bir inceleme gerçekleştirilecektir.

Filmin ilk bölümünde Makedonya'da, Makedonlar ve Arnavutlar dolayısıly Hıristiyanlar ve Müslümanlar arasındaki dini kaynaklı iç savaş, kargaşa konu edilir. Dini bakımdan birbirinden farklı olan bu iki topluluğun insanları aynı dili de konuşmazlar, belki de aynı dili konuşuyor olsalar birbirlerini anlayacak ve söz konusu düşmanlığa son vereceklerdir. Ancak toplulukların kullandıkları farklı dil onların farklı dini, etnik kimliklerini imler, buna paralel olarak bu farklıık onların birbirlerini ötekileştirmelerine yol açarak onlara yalnızca düşmanlık getirir.

Sözcükler adı verilen ilk epizodun başkahramanı Kiril Makedon kökenli bir Hıristiyan'dır, kendini Tanrı'ya adamış ve onun için iki yıl önce konuşmamaya yemin etmiştir. Dolayısıyla dil yani ‘sözcükler’ Kiril için bir anlam ifade etmez. Kiril ölümden kaçıp odasına sığınan, kendisiyle aynı dili konuşmayan Arnavut kökenli Müslüman Zamira'nın söylediklerini anlamaz. Farklı dilde ve kimlikteki bu iki genç, ait oldukları topluluklar arasındaki savaş, nefret ve düşmanlıkla karşıtlık çizen bir diyalog geliştirirler. Aralarında dilin yani 'sözcükler'in ötesinde bir iletişim şekillenir: sevgi. Dili yok saymak, farklı kimlikleri yok saymayı, bu da sevgiyi getirmiştir. Öyle ki onlar dilin sınırlarını aşmışlardır ancak bu sevgiyi yaşamaları dolayısıyla kavuşmaları ait oldukları etnik köken, konuştukları farklı dil, mensup oldukları dini inanç ve içinden geldikleri toplumla arasında hüküm süren savaş nedeniyle olanaksızdır.
Greimasçı göstergebilimde 'AI' şeklinde ifade edilen anlatı izlencesi terimi, başlangıç durumundan bitiş durumuna dek bir öznenin bir nesneyi araması, onun peşinde koşması sürecini karşılar (Kıran, 2007: 273). Bu epizottaki anlatı izlencesi Kiril ve Zamira'nın yani birlikteliği imkansız aşıkların birbirine kavuşma çabasıdır. Bu anlatı izlencesinde 'Ö' harfini karşılayan yani özne olan Kiril için ' $N$ ' harfini karşılayan yani nesne olan Zamira'dır aynı şekilde tersten okunursa özne Zamira olduğunda onun kavuşmak istediği, aşık olup peşinden gittiği nesne ise Kiril olarak düşünülebilir. İkisinin de birbirine kavuşmak istemesi, iki öznenin birbirinin peşinden gitmesi birleşme anlamına gelen U harfiyle temsil edilir. Söz konusu anlatı izlencesi bu doğrultuda aşağıdaki şekilde biçimlenir.

\section{Aİ: (Kiril) Ö U N (Zamira)}

(Kiril ve Zamira’nın kavuşması)

Böylece bu epizotta Kiril ve Zamira anlatının iki ayrı eyleyeni, iki ayrı öznesi olarak karşımıza çıkar. Aynı şekilde ikisi de birbiri için arzulanan ve elde edilmeye çalışılan değer nesnesidir. Greimasçı göstergebilimde anlatıda yer alan kişi, olgu ve değerler üç karşıt çifte indirgenir: özne-nesne, gönderici-alıcı, destekleyici-engelleyici. Özneden yana olanların tümüne destekleyici, olmayanlara da engelleyici denir (Moran, 2006:195-196). Birbirine kavuşma anlatısında birbiri için özne ve nesne olan Kiril ve Zamira'nın kavuşmasına engel teşkil eden kişi ve olgular Greimasçı göstergebilimin engelleyici kavramına denk düşer. Bu süreçte iki özne de ortak engelleyiciler karşısında çaresizdir: Zamira'nın ailesi, nefret, düşmanlık, dil-din-rrk farkı, ötekileştirilme, savaş, toplumsal normlar... İkisinin birbirine kavuşması karşısında birçok engel olmasına karşın kavuşmalarına destek olan bir yardımcı bulunmamaktadır. Özneyi bir şeyi araması, onu elde etmesi için görevlendiren gönderici, öznenin bu eyleminden yarar sağlayan ise alıcı olarak tanımlanır (Kıran, 2007: 280). Bu tanıma uygun olarak Zamira ve Kiril'i birbirine iten göndericiler aşk, sevgi ve arzu duygularıdır. Birbirlerine kavuştuğunda mutluluk duyacak, istediğini alacak, amacına ulaşacak olansa yine kendileridir, dolayısıyla bu düzlemde alıcı Zamire ve Kiril'dir. Bu tespitler Greimas göstergebiliminde 
önemli yeri olan ve her anlatıya uygulanabilen, burada açıklanan üç karşıt çifti içeren aşağıdaki şemayla özetlenebilir.

\section{Kiril ve Zamira'nın eylemsel şeması:}

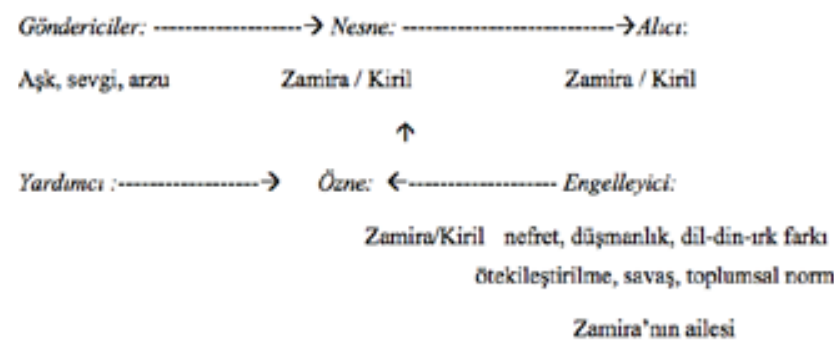

Engelleyici kutbunda yer alan olgular Kiril ve Zamira'nın birbirine kavuşması için kaçmaktan başka çare bulamamasına yol açmıştır. Ancak onlar kaçarken Zamira'nın peşinde olan ailesi onları bulur ve Zamira'nın ağabeyi bir Hıristiyan'a sığınıp onunla kaçmaya kalkarak namusunu kirleten Zamira’yı öldürür. Görüldüğü gibi eyleyenler arzu nesnesine kavuşma yolunda çabalamış, eylemlerde bulunmuş ve bir dönüşüm yaşamışlardır. Suçlu ama yaşayan bir kaçak olan Zamira epizot sonunda suçunun bedelini canıyla ödemiş bir ölü, huzurlu ve günahsız Kiril epizot sonunda acılı ve günahkardır. Anlatının hareket motoru olan başlangıç ve bitiş arasındaki bu farklılık $\rightarrow$ işaretiyle şöyle gösterilebilir:

\section{Başlangı̣ $\quad$ Bitiş \\ Zamira $\rightarrow$ Suçlu, yaşayan \\ Suçunun bedelini ödemiş, ölü \\ Kiril $\rightarrow$ Masum, huzurlu \\ Günahkar, acı dolu}

Zamira ve Kiril'in bir Arnavut ve bir Makedon ya da bir Hristiyan ve bir Müslüman olarak birlikte olma çabası, bu iki topluluk arasındaki savaş, düşmanlık, nefret, ötekileştirme karşısında olumlu bir alternatif olarak çizilmiş ancak birliktelik yenilgiye uğramış, olumsuz ve yıkıcı olgular kazanarak olumlu bir dönüşümün olanaksızlığı gösterilmiştir. Eyleyenlerin dönüşümü, koşulların olumluya dönüşmesinin imkansız olduğunun habercisi olmuştur.
Epizot sonunda barış, beraberlik, sevgi, yaşam bu topraklar üzerinde Kiril ve Zamira gibi yenik durumdadır. Zamira ve Kiri'in birbirine kavuşamadığı anlatı, başlangıç ve bitiş durumu arasında, toplumu ilgilendiren olumsuz bir dönüşüme neden olmuş bu dönüşüm ' $\rightarrow$ ' işaretiyle ortaya koyulmuştur.

Ayrılık: özne-nesne

Sevgi $\rightarrow$ Nefret

Barış $\rightarrow$ Savaş

Birlik $\rightarrow$ Ötekileştirme

Yaşam $\rightarrow$ Ölüm

Aynı analizi filmin ikinci epizoduna da uygulamak gerekir. Filmin Yüzler adlı ikinci bölümü Zamira ve Kiril'in bir önceki epizot kaçmakta olduğu Alex'in Londra'daki yaşamıyla başlar ancak bu bölümde önemli bir eyleyen de Alex'in sevgilisi Anne'dir. Dolayısıyla burada bir ikinci anlatı karşımıza çıkar, bu anlatıda öznelerden biri Alex diğeri Anne'dir. Aİ olarak yazılan ilk anlatı izlencesinin konusu Alex'in memleketine gitme arzusudur. Alex iki hafta kaldığı Bosna'da iyi bir fotoğraf için bir savaş esirinin ölümüne sebep olmuştur, şimdi vicdanını rahatlatmak için savaşın hüküm sürdüğü kendi topraklarına, Makedonya'ya dönmek istemektedir. Ö harfiyle ifade edilen özne Alex olduğunda onun ulaşmak istediği, $\mathrm{N}$ harfiyle ifade edilen nesne memleketi yani Makedonya olacaktır. Alex'in Makedonya'ya kavuşma isteği birleşmeyi ifade eden $U$ harfiyle simgeleştirilir. Böylece epizodun konusu somutluk kazanır.

\section{Aİ: (Alex) Ö u N ( Makedonya)}

(Alex’in ülkesine dönme arzusu)

Yine bir özne ile nesne arasında kavuşma çabası ortaya çıkmıştır. Bu çaba Greimasçı göstergebilimde yer alan karşıt üç çifti tekrar gündeme getirir. Özne Alex'i tetikleyen, yani onu nesne Makedonya'ya dönmeye iten göndericiler, bir savaş esirinin ölümüne neden olan hatası 
ve vicdanını rahatlatma fikridir. Amacına ulaştığında kazançlı çıkacak, rahatlayacak olan alıcı bizzat kendisidir. Ne var ki onun nesneye yani ülkesine kavuşması sürecinde karşısında önemli bir engelleyici vardır: Anne. Alex Anne ile birliktelik yaşamaktadır ve Alex'in eylemi Anne'yi de seçim yapmak zorunda bırakacaktır. Bunun yanında Alex’in gitmesine destek olan bir yardımcıya rastlanmaz.

Alex'in eylemsel şeması:

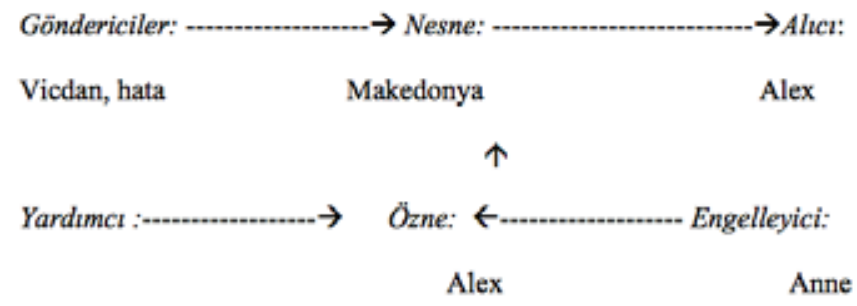

Alex'in kararı ve eylemi Anne'yi de bir karara ve eyleme sürükleyerek onu da eyleyene, ikinci bir özneye dönüştürür. Anne evlidir, hamiledir, Alex ile gayrı meşru bir ilişki yaşamaktadır ve onun ardından gitmek, eşi Nick’ten boşanmak istemektedir. Böylece ikinci bir özne olarak Anne için arzulanan ve kavuşulmak istenen değer nesnesi Alex olur ve bu epizot için ikinci bir anlatı izlencesi ortaya çıkar. Bu anlatının konusu Annie'nin Alex'in yanına gitme isteğidir. Bu istek yine bir bağlaşım çabası olduğundan özne ve nesne ilişkisi U harfiyle biçimlendirilmiştir.

\section{Aİ: (Anne) Ö U N (Alex)}

(Anne'nin Alex’in ardından gitme arzusu)

Anne'nin Alex'in ardından gitmesi için onu tetikleyen dolayısıyla Greimasçı göstergebilimin ifadesiyle göndericisi olan en önemli şey ona duyduğu aşktır, Alex’in yanına gittiğinde aşkına kavuşacak olduğundan bu anlatıda alıcı kendisidir. Onu engelleyen en belirleyici unsur ise Nick ile olan evliliğidir, onu destekleyen bir yardımcıya rastlanmaz. Böylece ikinci eyleyen Anne'nin durumu da üç karşıt çifti içeren eylemsel şema ile ortaya konulabilir.
Anne’nin eylemsel şeması:

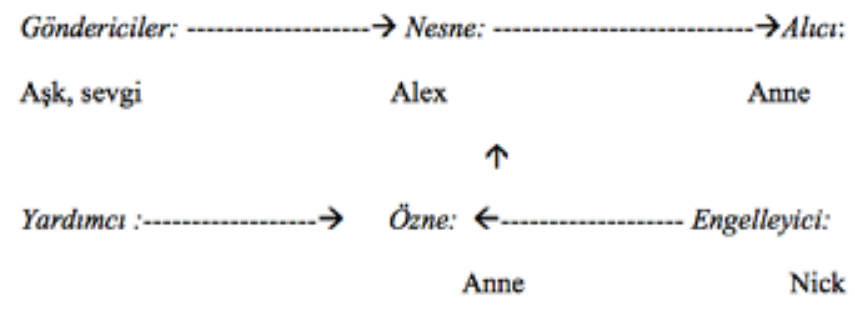

Anne Alex'in arkasından Makedonya'ya gitmek, bunun için de Nick'ten boşanmak yönünde karar alır, Londra'da bir restoranda yedikleri akşam yemeği sırasında bunu Nick'e açıklar. Bu sırada restoranda çıkan bir kavga nedeniyle restoran silahla taranır ve Nick ölür. Böylece ikinci eyleyen olarak Anne dolaylı da olsa Nick'in hayatında bir dönüşüme neden olmuş, önce onu terk etmiş ardından da ölümüne şahit olmuştur. Böylelikle bu epizotta da başlangıç durumuyla bitiş durumu arasında büyük bir değişim yaşanmış, anlatı yine bir dönüşüm üzerine kurulmuştur. Anlatının bu epizodunun temel konusu olan söz konusu değişim Greimas göstergebiliminde yer alan beşli şema ile özetlenebilir. Bu beşli şema anlatının beş önemli evresini içerir, bu evrelerden başlangıç ve bitiş farklı iki durumu içerir, düğüm dönüştürücü öğe, başlangıç durumundaki dengeyi bozan olay, eylem ise bu olaya kişilerin verdiği tepkidir, bu tepki çözümü gerçekleştirecek olaya sebep olur (Kıran, 2007: 301-303). Beşli şemadaki kavramların epizottaki karşılığına bakmak açıklayıcı olacaktır.

Başlangıç: Alex Londra'da Anne ile aşk yaşayan bir fotoğraf sanatçısıdır.

Düğüm: Alex Makedonya’ya dönmeye karar verir.

Eylem: Anne de Alex'in peşinden gitmek için eşi Nick'ten boşanmaya karar verir. Bir restoranda Nick'e bunu açıklar.

Çözüm: Anne Nick’ten ayrılır, restoran silahla taranır.

Bitiş: Nick ölmüştür. 
Bu noktada ilk iki epizoda uygulanan anlatı düzeyini inceleme yöntemini son epizoda da uygulamak gerekir. Alex'in Makedonya'ya dönmesiyle üçüncü epizot başlar. Alex tam da istediği gibi ülkesinde, savaşın göbeğindedir. Savaş onun bıraktığından çok daha yıkıcı ve çetindir. Öyle ki bir Hıristiyan olarak Müslüman mahallesine girmesi bile zorlaşmıştır. Eski sevgilisi Hanna Müslümandır, Alex onu ve ailesini ziyarete gittiğinde Hanna'nın kızı Zamira'nın kendi kızı olduğunu anlar. Böylece tüm epizotlardaki anlatılar büyük bir anlatıya bağlanır. Alex filmin ilk epizodundaki Kiril'in amcası olmanın yanı sıra Zamira'nın da babasıdır. Bu epizotta Zamira Hristiyan Bojan'ı öldürdüğü suçlamasıyla aranacak ve peşindekilerden kaçıp Kiril'in evine sığınacak, Alex kızı olduğu için onu korumaya çalışırken ölecektir. Böylece ilk epizot filmin şimdisi ve finali olup ikinci ve üçüncü epizot ilk epizot yaşananların geçmişidir. Zira filmin başında görülen, Alex'in ardından geldiği anlaşılan Anne tarafından da izlenen cenaze, Alex'in cenazesi olup ilk epizodun filmin şimdisi ve finali, ikinci ve üçüncü epizodun da filmin geçmişi olduğu savını doğrular. Epizotlara bölünmüş anlatının zamansal dizilimi şöyle özetlenebilir.

\begin{tabular}{ll}
\multicolumn{1}{c}{ 'Geçmiş' } & \multicolumn{1}{c}{ 'Şimdi' } \\
Ikinci ve Oçüncũ Epizot & Birinci Epizot \\
Alex'in Londra'dan aynlması & Zamira'nın Kiril'e sığınması \\
Zamira'nın suçlanması & Anne'nin gelmesi \\
Alex'in Zamira'yı koruması & Alex'in cenazesi \\
Alex'in ölmesi & Kiril ve Zamira aşkı, Zamira'nın ölūmü
\end{tabular}

Böylece son epizotta, önceki epizotlardan tanınan iki eyleyen özne, yeni nesnelerin peşinde bir kez daha görülür. Zamira'nın kendi kızı olduğunu öğrenen Alex onu korumanın, ölümden kurtarmanın peşindedir. Aslında bu ikinci epizotta Makedonya'ya dönme kararını tetikleyen göndericilerden vicdanını rahatlatma isteğinin bir göstergesidir. Tam da istediği gibi savaşın ortasına düşmüş, daha önce savaşta birinin ölümüne sebep olan Alex, burada savaş yüzünden kızı için ölerek vicdanını rahatlatmış, amacına ulaşmıştır. Son epizottaki anlatı izlencesi Alex'in savaşta yer alma ve kızını koruma çabasını içerir. Özne Alex için Zamira'nın hayatı ulaşılmak istenen hedef yani nesnedir. Bu epizotta Alex amacına ulaşmıştır, bu durum kavuşma ve ulaşmanın simgesi olan $\cap$ ile gösterilebilir.

\section{Aİ: (Alex) $0 \ddot{N} \cap \mathrm{N}$ (Kızının hayatı)}

(Alex'in savaşta aktif rol oynama ve kızını koruma arzusu)

Alex'in kuzeni Bojan'ın yanında en son görüldüğü için ve Müslüman bir Arnavut yani düşman olduğu için Zamira suçlanmakta, Bojan'ın ölümünden o sorumlu tutulmaktadır. Zamira bu nitelikleri nedeniyle potansiyel suçlu durumundadır. Alex'in ailesinden kaçan Zamira'nın bu epizottaki hedefi dolayısıyla arzu nesnesi hayatta kalma isteğidir ve bu epizotta kaçarak bunu başarır. Zamira belki kendinden farklı bir dil konuşan bu insanların neden kendisinin peşinde olduğunu bile bilmez, kendini anlatamaz, savaş ortamında yalnızca öldürüleceğinin farkına varır, yapabileceği tek şey kaçmaktır. Zamira'nın kaçışı bu epizodun bir başka anlatı izlencesidir. Zamira bu epizotta kaçmayı başarmış, amacına ulaşmış olduğundan onun nesne ile ilişkisi kavuşmanın simgesi olan $\cap$ işaretiyle gösterilebilir.

\section{Aİ: (Zamira) Ö $\cap N$ ( kurtulmak) \\ (Zamira'nın hayatta kalmak için kaçması)}

Bir özne olarak Alex'in değer nesnesi olan Zamira'yı kurtarma çabasında rol oynayan, dolayısıyla onun bu eyleminde gönderici rolünü üstlenen kuşkusuz öncelikle onun babası olmasından dolayı duyduğu evlat sevgisidir. Ama aynı zamanda bu topraklara gelerek savaşta aktif olmak, vicdanını rahatlatmak isteği de bunda dolaylı olarak rol oynamıştır. Alex amacına ulaşırsa hem kendisi hem de Zamira bundan fayda görecek olan alıcılardır. Ne var ki ailesi, düşmanlık, nefret, savaş, ötekileştirme onun bu çabası karşısındaki engelleyiciler olarak canını alacaktır zira bu çabasında onu destekleyen bir yardımcısı yoktur. 
Alex’in eylemsel şeması:

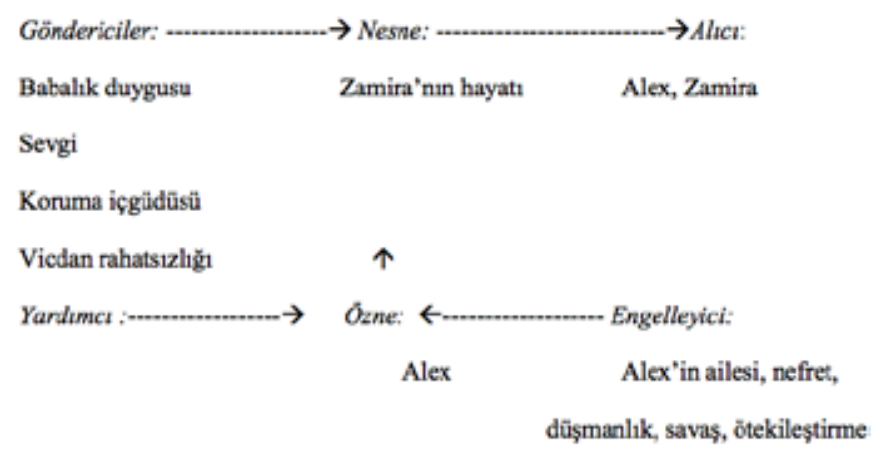

Zamira'nın bu epizottaki çabası ya da arzu nesnesi yaşamdır, canını kurtarmaktır. Bunun için dilini bilmediği bu kişilere açıklama da yapamayacağından kaçmak zorunda kalmıştır. Gençliği, ölüm korkusu, kendini ifade edemeyişi onu bu kaçışa zorlamış, eyleminde gönderici olmuştur, bu yolda babası olduğunu bilmediği Alex yardımcısı olmuş, Alex'in ailesi, nefret, düşmanlık, savaş, ötekileştirme onun yaşamı için de engelleyici bir tehdit unsuru durumuna gelmiştir. Bu epizotta bu engelleyicilere takılmayıp hayatta kalan Zamira alıcı olarak amacına ulaşmış durumdadır ancak ilk epizotta ölmüştür dolayısıyla bu epizodun geleceğinde, filmin şimdisinde ölmekten kurtulamayacaktır.

Zamira'nın eylemsel şeması:

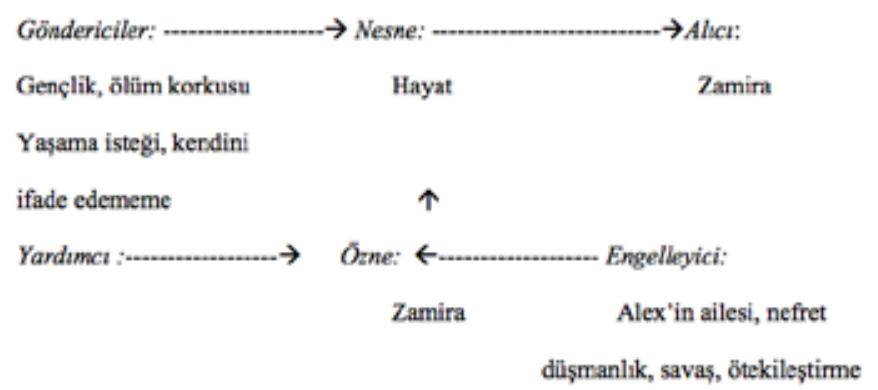

Epizodun sonunda eyleyenlerin ikisi de büyük dönüşüme uğramıştır. Zamira masum bir şekilde sıradan bir hayat sürerken artık günahkar ve suçlu durumda kaçak bir hayat sürdürmektedir; Alex ise herhangi bir birey olmaktan baba olmaya geçmiş daha önemlisi yaşamdan ölüme, vicdan azabından huzura doğru bir dönüşüm gerçekleştirmiş̧ir. Ancak bu epizotun dolayısıyla filmin sonunda en büyük dönüşüm seyirci tarafından yaşanır. Artık seyirci ilk epizotta olanların anlamını ve zamanlamasını daha iyi bilmektedir, zihninde anlatının tüm taşları yerine oturmuş, soruları cevap bulmuş ve eyleyenlerle birlikte o da dönüşmüş durumdadır. Anlatının varlığını sağlayan temel öğe olan dönüşüm bu epizotta bir kez daha derinden yaşanır ve ' $\rightarrow$ ' işaretiyle görselleştirilebilir.

\begin{tabular}{|c|c|c|}
\hline & Baslangs & Bitiş \\
\hline Zarnira $\rightarrow$ & $\begin{array}{l}\text { Masum, } \\
\text { sıradan bir yaşam içinde }\end{array}$ & Suçlu, kaçak, korkulu \\
\hline Alex $\rightarrow$ & $\begin{array}{l}\text { Herhangi biri, vicdanı rahatsız, } \\
\text { yaşayan }\end{array}$ & Baba, huzurlu, ölū \\
\hline Seyirci $\rightarrow$ & $\begin{array}{l}\text { Kafasincla soru isaretleri var, } \\
\text { Anlatı zamanının tam bilineinde degil }\end{array}$ & $\begin{array}{l}\text { Cevapları bulmuş, her șeyin } \\
\text { farkında, zamanın } \\
\text { bilineinde }\end{array}$ \\
\hline
\end{tabular}

Görüldüğü gibi filmde üç epizot da kendi içinde birçok anlatı barındırmakta, bu nedenle her bir anlatı tek tek başlı başına incelenip birbiriyle ilişkilendirilerek büyük anlatının resmi ortaya çıkmaktadır. Zira olay ya da düşünce anlatan bir konuşma veya yazıda bir değil birden çok anlatının yer aldığı söz konusu konuşma ya da yazının, bu yalın anlatıların birbiriyle birleşerek oluşturdukları bir bütün olduğu söylenebilir (Yücel, 2005: 151). Bu saptama kişiler arası konuşmalarla örülü, yazılı bir senaryo metnine dayanan söz konusu sinema filmi için de geçerlidir. Böylelikle üç epizot üzerinden ayrı ayrı çözümlenerek bütünlenen filmdeki anlatı Greimas göstergebiliminin şemalarıyla somutlanarak filmin yüzey yapısının anlatı düzeyi şekillenmiştir. Ne var ki yüzey yapıda yer alan sadece anlatı değildir. Kişiler, tekrarlanan sözler ve cümleler, kullanılan nesneler, özellikle söz konusu eser bir sinema filmi olduğundan vurguyla tekrar edilen görüntüler de bu çözümlemeyi derindeki anlama bağlayacak önemli betisel unsurlar olarak yüzey yapıda yer alır. Bu nedenle sıradaki başlıkta betisel düzey incelenerek yüzey yapıdan derin yapıya geçiş için önemli bir köprü kurulması sağlanacaktır.

\section{1. 2. Betisel Düzey}

Göstergebilimde yüzey yapının ikinci aşamasını oluşturan ve derin yapıdaki anlamlara geçiş olanağı sağlaması 
nedeniyle önemli bir yerde duran betisel düzey şu şekilde tanımlanmaktadır: çeşitli kavram ve işlemlerin kullanıldığı ve incelenecek gösterge dizgesinin betimlendiği düzeydir. Böylece inceleme konusu açıklayıcı bir dil aracılı̆̆ıla bir başka düzeye aktarılır (Rıfat, 2005: 201). Bu çerçevede daha açı bir deyişle betisel düzey anlatı dizgeleri ve olayların incelenmesinden sonra, anlatıda yer alan gösterge niteliğindeki öğelerin tek tek saptanıp incelendikten sonra anlatının bağlamı içerisinde, tutarlı bir şekilde anlama bağlanmasını içerir.

Film okumasının bu aşamasında betisel düzeyi oluştran, bu düzeyde çözümlenecek olan çok sayıda gösterge mevcuttur. Filmde tekrarlanan, vurgulanan, bu haliyle kendinden başka daha derin bir anlama hizmet ettiği anlaşılan birçok gösterge saptanabilir. Bu göstergeler tek başına, bağımsız bir olgu olarak değil filmin sunduğu dünya içerisinde anlamlandırılacaktır. Şöyle ki sözcüklerin anlamları yoktur, kullanımları vardır, konuşmada ya da söylemde bize iletildiği biçimiyle anlam, sözcüğün aynı bağlamdaki öbür sözcüklerle kurduğu ilişkilere bağlıdır. Mesela kırmızı sözcüğünün değerleri bunun da sonucu olarak kullanımları dilde turuncu, pembe, erguvan vb. terimlerin bulunmasına ya da bulunmamasına bağlıdır (Guiraud, 1999: 34). Nasıl ki dilde bir gösterge olan sözcüğün anlamı diğer sözcüklerle olan benzerliğine, farklılığına yani ilişkisine göre belirleniyorsa anlatıya dayanan filmde de göstergeler filmin sunduğu dünya içindeki diğer göstergelerle olan ilişkisine göre anlam kazanacaktır. Yani betisel düzeyde her bir göstergenin karşılığı olarak tespit edilecek olan anlam ya da anlamlar sadece bu filmin sınırları içinde geçerlidir, bu filmin içindeki diğer öğelerle birlikte anlam-gösterge ilişkisi gerekçelendirilecek, yorumlar tutarlı hale gelecektir. Önemli olan göstergelere yüklenecek olan anlamların filmdeki diğer göstergelerle ilişkili olarak, filmin bağlamı içerisinde mantıklı bir yere oturmasıdır.

"Toplum yaşamında sesli dil göstergeleriyle yazı göstergeleri dışında daha birçok gösterge yer alır" (Vardar, 2001: 84). Yağmurdan Önce adlı filmde de birçok dilsel gösterge ya da dil göstergesi yani altında önemli anlamlar barındıran, tekrar edilen veya vurgulanan sözler ve cümleler bulunmaktadır, burada öncelikle bu dil göstergeleri anlamlandırılacak ardından görsel gösterge diyebileceğimiz gösterge niteliği taşıyan görüntülere ilişkin yorumlar yapılacaktır.

Film üç epizottan oluşur ve her bölüme o bölümde anlatılacaklarlailgiliizleyiciyi hazırlayan veanlatılacakların odak noktası olan başlıklar verilmiştir. Bu bakımdan epizotların başlıkları anlam açısından işlevsel olmaları bağlamında birer dilsel gösterge olarak düşünülebilir. Zira epizot başlığı olan sözcük dikkati üzerine çekmekte, seyirciyi üstüne düşünmeye, anlam aramaya itmektedir. Bu bağlamda epizotlardan ilkine ‘sözcükler' başlığı verilmiştir ve bu bölüme genel olarak bakıldığında 'sözcükler'in bir gösterge olarak başka bir anlamı etkili bir şekilde verdiği, ötekileştirmenin, düşmanlığın, günahın göstergesi haline geldiği görülmektedir.

‘sözcükler’ ötekileştirme, düşmanlık, günah, savaş

Kiril Zamira'ya aşık olduktan sonra rahibe her şeyi anlatmış hem Tanrı için ettiği sessizlik yeminini bozmuş hem de bir Müslüman’ı odasında saklayıp ona aşık olarak büyük günah işlemiştir. Dolayısıyla Kiril için ‘sözcükler’ günahın kaynağı olmuştur. Nitekim Kiril'in konuşması gençlerin başına gelecek felaketlerin de yolunu açmıştır. Zamira ve Kiril kaçarken Zamira'nın ailesi onları bulur, ağabeyi Zamira'yı arkasından vurur. Zamira ölmek üzereyken Kiril ona ilk defa kendi dilinde onu sevdiğini söylemeye kalkar ancak Zamira Kiril'e susmasını işaret eder. Bu bölümün bu sahneyle son bulması oldukça anlamlıdır. Toplulukların birbirini anlamayıp ötekileştirmesine neden olan sözcükler dilin sınırlarını aşan bu iki gencin hayatına da girmiş ve onların başına yalnız felaket getirmiştir. 'Sözcükler'den dolayımla dilin yalnız düşmanlık, ötekileştirme, nefret ve günahın göstergesi olduğu bu ortamda belki de en iyisi epizodun finalinde Zamira'nın da işaret ettiği gibi susmaktır. Konuşmanın aksine susmak barış, birlik ve sevgiyi getirebilir. Böylece susmak farklı dilde konuşup anlaşamamak yerine iyi bir alternatif haline gelir, buradan da konuşmak ve susmak arasından doğan bir dizi karşıtlık türer. Bu karşıtlıklar karşıt taraflar anlamına gelen 'kt' kısaltmasıyla aşağıda gösterilmektedir. 


$\begin{array}{lll}\text { sözcükler } & \text { kt } & \text { suskunluk } \\ \text { konuşmak } & \text { kt } & \text { susmak } \\ \text { ötekilik } & \text { kt } & \text { birlik } \\ \text { savaş } & \text { kt } & \text { barış } \\ \text { nefret } & \text { kt } & \text { sevgi }\end{array}$

Aynı şekilde ikinci epizodun başlığı da 'yüzler' adını alarak, izleyicinin gözlerini bu bölümdeki kahramanların yüzlerine ayrı bir dikkatle bakmaya ve anlam aramaya yönlendirir. Böylece yüzler sözcüğü de bir dilsel gösterge olarak çözümlenmeyi gerektirir. İkinci epizotta yüzler üzerine düşünmeyi sağlayan ilk şey Bosna'da yaşadıklarının Alex'in yüzüne yansımış olmasıdır, Anne'nin söylediğine göre (Manchevski, 1994) iki hafta içinde yaşadığı değişim Alex'in yüzünden okunmaktadır. Gerçekten de bu geçen iki hafta içinde Alex birinin ölümüne neden olmuş, bu yaşadığı şey onu değiştirmiş ve Bosna'dan az sonra açıklayacağı radikal bir kararla dönmüştür. Dolayısıyla yüzler başlığı altında önemli bir anlam olarak yaşananların yarattığı değişimi, dönüşümü barındıran dilsel bir gösterge olarak düşünülebilir.

\section{‘yüzler’ değişim, dönüşüm, yaşananların izleri}

Alex Bosna'dan dönüp sevgilisi Anne ile buluştuktan sonra taksiye bindiğinde Makedonya'ya dönme kararını Anne'ye bildirirken çok önemli bir cümle sarf eder: "barış bir istisnadır, bir kural değil” (Manchievski, 1994). Bu cümle de bir dilsel göstergedir. Çünkü burada Alex dolaylı olarak savaşın her yerde olduğunu söylemektedir. Zira bu bölümün son sahnesinde savaşın kentsel yüzü açıkça görülür. Makedonya'da etnik ya da dini kaynaklı nedenlerle yaşanan iç savaş, burada zengin bir adamın öfke patlamasıyla bir restoran dolusu insanı öldürmesine dönüşmüştür. Şiddet, ölüm ve kan yani savaş Alex'in de ifade ettiği gibi her yerdedir, yalnızca yaşanma biçimi ve onu yaşayan insanların yüzleri birbirinden farklıdır. Aynı sahnede Nick ölmeden hemen önce bu öfkeli adamın Ulster'dan olup olmadığını sorar. Nick için adamın İngilizlerin yaşadığı Ulster bölgesinden olması bu adamın yanlış tavrının gerekçesi olacaktır. Amerikalılar muhtemelen bu bölgeden olanları ötekileştirir, bu durum Nick'in sorusuna açıkça yansır. Bu bakımdan denilebilir ki Makedonya'da savaşın kaynağı olan ötekileştirme Londra'da da yaşanmaktadır. Diğer yandan Makedonya'da bir köylünün dinlediği müzik, bu epizotta Londra'da mezarlıkta bir kızın walkmanından yükselerek etrafa yayılır; bu bölümde gördüğümüz insanların kıyafetleri Makedonya'daki insanların kıyafetleriyle ayn markadadır. Bütün bunlar bir arada düşünüldüğünde 'yüzler' başlığı genelde yaşananların benzerliğini özelde şiddet, savaş ve ötekileştirmenin her yerdeki mevcudiyetini anlatan dilsel bir gösterge kimliğine bürünür. Nitekim epizodun sonunda Nick yüzü parçalanarak ölür. Kameranın odaklandığı bu görüntü yüzler göstergesinin taşıdığı anlamı etkili şekilde iletir. Dünyanın her yerinde yaşananlar aynıdır: savaş, nefret, şiddet. Değişen tek şey yüzlerdir. Bu durum aşağıdaki karşıtlık ekseniyle şöyle gösterilebilir.

$\begin{array}{lll}\text { Yüzler } & \text { kt } & \text { yaşananlar } \\ \text { Farkl, değişik } & \text { kt } & \text { aynı, benzer }\end{array}$

Üçüncü epizoda adını veren 'fotoğraflar' sözcüğü de önceki iki epizotta olduğu gibi bir gösterge olarak seyircinin onun içinde barındırdığı anlama odaklanmasını sağlar. Üçüncü bölüm Pulitzer ödülü almış bir fotoğrafçı olan Alex'in yaşamının nasıl sonlandığını konu alır. Dolayısıyla bir fotoğrafçıyı konu aldığı için son bölüme bu başlığın verilmiş olması konu bütünlüğü açısından doğal görünmektedir. Bununla beraber başlığın hizmet ettiği anlamın niteliği bölümün geneline bakıldığında ortaya çıkar. Pulitzer ödüllü bir fotoğrafçı olan Alex Makedonya’ya döndüğü bu bölümde mesleğini bırakmıştır. üçüncü bölümde Alex’in savaşın kol gezdiği kendi topraklarına geri dönerken fotoğraf çekmeyi, fotoğraf makinesini bıraktığına, ödüllü fotoğraflarının bulunduğu kitabı bir masayı yükseltmek için masanın ayağının altına koyacak kadar değersiz gördüğüne tanık oluruz. Çünkü daha önce de söylendiği gibi Alex Bosna'da etkili kare yakalamak için bir savaş esirinin ölümüne neden olmakla başlayan vicdan azabını savaşta bizzat yer alarak, taraf olarak, 
savaş nedeniyle ölerek, kendi ölümünün fotoğraflanmasına izin vererek dindirmek ister. Yani Alex için Makedonya'ya dönüş aslında ölüme gidiştir. Alex öleceğini bile bile Makedonya'ya gider, yaşamını bir bakıma kendi sonlandırarak yaptığı hatanın bedelini ödemek ister. Bu istekle fotoğraf çekmeyi bırakması anlamlıdır. Bugüne dek hep savaş fotoğrafları çeken hatta o fotoğraflarla ödül alan Alex hiçbir fotoğrafa konu olmamıştır, hep objektifin arkasında durmuş, hiç önüne geçmemiştir. Yani kendi toprakları da dahil olmak üzere her yerde yaşanan savaşa hep seyirci kalmış, onu gözlemlemiş hatta savaştan para, ödül kazanmış ama hiç taraf olmamıştır. Bu bakımdan Alex'in kararı 'fotoğraf'lar çekmek ya da 'fotoğraflar'ın malzemesi olmak seçeneklerinden birini tercih etmenin anlamını dışa vurur, bu tercih savaşta taraf olmak ya da tarafsız kalmak arasındaki tercihtir. Alex taraf olmayı, ölmeyi, objektifin arkasından önüne geçmeyi seçmiştir. Böylece fotoğraflar başlığı bir gösterge olarak anlam kazanır, karşıt seçenekler arasında yapılan bir tercihin dışavurumunu sunar. Aşağıda fotoğraflardan türeyen karşıt seçeneklerin ne olduğu açıkça görülmektedir.

$\begin{array}{llll}\text { fotoğraf çekmek } & \text { kt } & \text { fotoğrafa malzeme olmak } \\ \text { objektifin arkasında durmak } & \text { kt } & \text { objektifin önüne geçmek } \\ \text { savaşta pasif kalmak } & \text { kt } & \text { savaşta taraf olmak }\end{array}$

Alex öldürüldükten sonra cenazesi sırasında küçük bir çocuk onun fotoğraf makinesiyle onun fotoğrafını çeker. Alex artık işine yaramayan makineyi o çocuğa oyuncak diye vermiş̧ir. Kim bilir belki Alex de fotoğraf çekmeye böyle başlamıştır ya da o küçük çocuk ileride Alex’le benzer şekilde objektifin önüne geçmeyi tercih edecektir. Her ne olursa olsun fotoğraflar karşısındaki tercih belirleyicidir. Böylece 'fotoğraflar' önemli anlamların hizmetinde dilsel bir gösterge olarak bu bölüme adını vermiş ve Alex'in seçiminden dolayımla bu bölümün merkezine oturmuştur.

Filmde başlıkların yanında tekrar tekrar vurguyla gösterilen kimi görüntü ve nesneler de anlama giden yolu aydınlatmada önemli bir işleve sahiptir. Filmin hem birinci hem de ikinci bölümünde kameranın odaklandığı dikkat çeken görüntülerden biri kaplumbağalardır, bu durum seyirciyi kaplumbağaların hizmet ettiği anlama dair düşünmeye sevk eder. Bunun için kaplumbağaların gösterildiği yerlere ve gösteriliş biçimine bakmak gerekir. İlk bölümde Kiril kilisede ayindeyken dışarıda çocuklar bir kaplumbağayı ters çevirmiş, çevresini bir çemberle kuşatmışlardır, az sonra üzerine mermi boşaltırlar, kaplumbağa ölür, Kiril bu ses ile irkilir. Bu trajik sahne kaplumbağanın çaresizliği nedeniyle yaşanır. Filmin ilerleyen bölümleriyle birlikte düşünüldüğünde bu kaplumbağaların filmdeki savaş ortamında yaşayan tüm kişileri temsil ettiği anlaşııı. Savaş çemberi tarafından kuşatılmış olarak bu topraklarda yaşayan insanlar da ölüme mahkumdur, tıpkı o kaplumbağa gibi çaresizdir. Bu bakımdan söz konusu sahnedeki kaplumbağa ile bu ortamdaki insanlar arasında bir özdeşlik kurulmuştur.

İkinci bölümde ise bir başka kaplumbağayı Londra'da, lüks bir restoranda, ışıklı bir akvaryumun içinde görürüz. Bu kaplumbağa akvaryumun korunaklı dünyası içinde fiziki olarak ölümden uzaktır ama doğal ortamından alınmış, özgürlükten uzak, camın ardına hapsedilmiş yaşayan bir ölü olmuştur. Tıpkı Londra'nın gökdelenlerle çevrili kent yaşamında kendini özgür hissetmeyen, sıkışmış, savaşı farklı bir boyutta yaşayan şehir insanı gibi... Gerek akvaryumdaki kaplumbağa gerek şehir insanı ölümü manevi boyutta yaşar, çaresizdir. Burada da söz konusu kaplumbağa ile şehir ortamındaki insanlar özdeşleştirilmiştir. Ayrıca epizodun sonunda bu kaplumbağanın korunaklı dünyası restoranın taranması nedeniyle yıkılır, ne kadar korunursa korunsun onun da ilk epizottaki kaplumbağadan farkı yoktur, tehlike içinde, çaresizdir. Son kertede kaplumbağa farklı mekanlarda ölüme terk edilmiş çaresiz insanların göstergesi olur. Böylece kaplumbağa göstergesinde bütünleşen gösteren gösterilen yani görüntü anlam ilişkisi açığa çıkar.

‘kaplumbağalar' savaş ve nefret ortamında yaşayan çaresiz insanlar

Filmin üç epizodu da ölümle sonlanır: Zamira'nın ölümü, Nick'in ölümü, Alex’in ölümü. Bojan'ın ölümünden sorumlu tutulan Zamira ölümden kaçarken bir Hıristiyan'a 
aşık olduğu için öz ağabeyi tarafından öldürülür. Zamira'yı hem günahsız olduğu düşüncesiyle hem kendi kızı olma ihtimali nedeniyle korumak isteyen Alex ise kuzeni tarafından öldürülür. Alex ölürken Zamira hayattadır, Zamira öldüğünde Kiril. Belki Kiril ölürken bir başkası hayatta kalacak bu ölüm döngüsü böyle sürecektir. İlk epizodun sonunda Zamira, son epizotta Alex ağacın önünde ölür. Bu iki ölümün nedeni savaştır ancak filmin ikinci epizodunda Nick'in Londra'da bir restoranda gerçekleşen ölümü görece nedensizdir. Zengin bir adamın öfkesine kapılarak restoranı taraması Nick ile beraber birçok masum insanın ölümüne neden olur. Dolayısıyla mekan farklıdır ama öfke ve ölüm burada da vardır. Dikkate değer bir nokta Nick'in de bir ağaç önünde ölmesidir ama bu ağaç saksının içinde bir süs bitkisidir. Tıpkı kaplumbağaların ancak akvaryumda görülmesi gibi bu kent ortamında ağaçlar da doğal ortamında değil saksılarda görülebilmektedir.

Bütün bunlar gösterir ki filmdeki üç ölüm de aynı nedenlerle gerçekleşir, benzer nitelikler taşır ve hepsi doğal ya da yapay bir ağacın önünde yaşanır. Bu durum ağacı yalnızca bir fon olarak değerlendirmeyi olanaksızlaştırır, ona bir gösterge işlevi yükler. Ağaçların kökleri ölülerin kanlarıla sulanır, ölüm, kan, şiddet ağaçlarla birlikte yaşamına devam eder, böylece ağaç şiddet ve ölümü sonsuzlaştırır, bunun sonsuz ve kaçınılmaz bir döngü olduğunu gösterir. Mekanlar birbirine benzemese de ölümlerin ve savaşın yaşanma biçimleri farklı olsa da fonda duran ağaç, ölüm, savaş, şiddet, nefret ve kanın her yerde, kaçınılmaz ve sonsuz olduğunu göstermektedir. Ağaç bu anlama işaret eden bir gösterge olarak tutarlı bir yere oturmaktadır.

‘ağaçlar' kaçınılmaz savaş, şiddet, nefret, kan döngüsü

Savaştan, şiddetten, ölümden kaçan Alex bu kaçışın sonunda tam da onun kucağına düşer ve ağacın önünde ölür. Alex savaştan uzak kalmak için fotoğraf çekmeyi, Makedonya'dan Londra'ya gitmeyi tercih etmiş ancak savaş onu elindeki makinede yakalamıştır. Fotoğraf çekerek bir insanın canını almıştır. Alex'in fotoğraf çekmeyi bırakmasına neden olan, onun Makedonya'ya dönmesini tetikleyen şey sanatını, iyi bir fotoğrafı, bir insanın hayatına yeğlemiş olmasının verdiği acıdır. Bu çerçevede Alex'in gözünde artık fotoğraf makinesi silahtan farksızdır çünkü tıpkı silah gibi o da bir can almış, onu kullanmakla kendisi de bir anlamda katil olmuştur. Fotoğraf makinesinin silahla özdeş kimliği filmin çeşitli sahnelerinde doğrudan gösterilir. Söz gelimi Alex kendisine ve makinesine pencereden bakan çocukların fotoğrafını çekmek üzere makinesini eline aldığında, çocuklar silah görmüşşesine irkilerek pencerenin altına saklanır. Bu bakımdan fotoğraf makinesi Alex'in bakış açısıyla silahın yerini tutan bir gösterge olarak sunulur. Gösteren kutbundaki fotoğraf makinesi görüntüsünün karşısındaki gösterilen kutbunda çağrışım ilişkisiyle farklı bir nesne olan silah koyulur.

'fotoğraf makinesi' silah

Filmde ilk epizotta rahibin kilisedeki ayin sırasında söylediği "zaman bitmez çember asla yuvarlak değildir" (Manchievski,1994) şeklindeki sözleri, ikinci epizotta bir duvar yazısı olarak Londra'da görülür. Bu durum, bu cümleyi dilsel bir gösterge olarak kabul edip üzerine düşünmeyi ve 'çember' ifadesine, anlam barındıran bir gösterge olarak eğilmeyi gerekli kılar. Bilindiği gibi çember bir başlangıç noktasından dairesel hareketle çizilen ve başlangıç noktasına gelerek tamamlanan bir şekildir, bu yönüyle döngüselliği imler. Filmin genelinde daha önce işaret edilen çeşitli göstergeler aracılığıyla şiddet, ölüm ve savaşın kaçınılmaz, sonsuz, insanı çaresiz hale getiren döngüsel niteliğine vurgu yapıldığı görülmüştür. Şiddet ancak şiddetle çözülür, bu yüzden şiddet karşı şiddeti doğurur, böylece şiddet sonsuzlaşarak içinden çıkılmaz kısır bir döngü halini alır. Bu nedenle çember filmin bütünü içinde öncelikle içinden çıkılamayan ölüm, şiddet ve savaşın kısır döngüsünü temsil eder.

'Çember'in savaş döngüsünü simgelemesi üzerinden insanlık tarihine bakılarak bir başka yoruma daha gidilebilir. İnsanlık tarihi boyunca savaşlar olmuş, taraflar, kazanan ve kaybedenler, savaşma biçimleri değişmiş ama savaş ve ölüm baki kalmıştır. Hatta bu nedenle tarihin tekerrürden yani tekrarlardan ibaret olduğu dahi söylenmiştir. Tekerrürden ibaret olan tarih de döngüsel bir hareketle ilerlemiş yani çember çizmiştir. İnsanlık tarihi 
savaşlarla başlamıştır, savaşlarla bitecektir ama o savaşları çıkaran insanlar aynı kalmamış hep değişmiş ‘ilerlemiş’tir. Bu yorum da savaşlarla dolu tarih üzerinden 'çember'in savaş, ölüm döngüsünü simgelediğini haklı çıkarır.

Filmde görsel olarak bütün mekanlar ya tam ya da yarım çember olarak çizilmiştir. Bu durum da çemberi bir gösterge olarak merkeze koymamıza neden olur. Bilindiği gibi çember aynı zamanda çıkışsızlığı, içinden çıkamamayı, dışarıdan da içeri bir şey alamamayı akla getirir. Filmde savaş ve şiddetten dolayımla, sudan sebeplerle toplulukların hatta insanların birbirini ötekileştirmesi eleştirinin temel hedefidir. Bu açıdan filmin bağlamı içinde 'çember' ötekiliğin simgesi olarak yorumlanabilir, birbirini dışlayan her topluluk bir nevi dışarı kapalı bir çemberdir. Nitekim Londra'ya geçildiğinde çemberlerin yerini siteler alır. Kamera kendi içinde her imkana sahip ancak dışarıya kapalı siteleri görüntüler. Buradan hareketle söz konusu sitelerin de birer çember olarak düşünüldüğü, ötekileştirmenin kentsel görünümünün böyle sunulduğu kuvvetle muhtemeldir. Bütün bunlar bir gösterge olarak çemberin filmin anlam evreninde çağrıştırdığı anlamlardır.

'çember' savaş, ölüm ve şiddete dayalı kısır döngü, insanlık tarihi, ötekileştirme

Bunun yanında filmde hem içerik hem de biçim olarak çember çizilir. Öncelikle Alex filmin son bölümünde on altı yıl sonra Makedonya'ya, bir başka deyişle hayata başladığı yere geri döner. Ama ne Makedonya ne de Alex aynı değildir. İlk aşık olduğu kadın olan Hanna, yaşadığı ev çok değişmiştir. Alex de bu süreçte çok değişmiştir öyle ki ilk etapta kendi kuzenleri dahi onu tanımaz. Dolayısıyla Alex'in Makedonya'ya gelişiyle zaman geçmiş, çember tamamlanmıştır ama süreç başlangıç noktasıyla bitiş noktası arasında fark yaratmıştır, araya zaman yani değişim girmiştir. Film biçim olarak da çember şeklinde kurgulanmıştır, şimdiki zaman ile başlar, geleceğe doğru devam ederek final gösterilir, ikinci ve üçüncü epizotta geçmiş zamana gidilir, film başladığı noktada, şimdiki zamanda biter. Bu bağlamda izleyici filmi izlemeye başladığı noktaya geri döner, izleyicinin seyir biçimi de çember olarak kurgulanır. Ancak filmin başındaki izleyiciyle sonundaki izleyici aynı değildir, tıpkı Alex gibi kendine sunulanlar karşısında o da çok değişmiştir. Finale geldiğinde ilk bölümün anlamı onun için farklılaşmıştır. Böylece "zaman bitmez çember asla yuvarlak değildir" (Manchievski, 1994) cümlesi dilsel bir gösterge olarak kabul edilirse, zamanın durmadan aktığını, önüne gelen her şeyi özellikle de insanı değiştirdiğini, görünürde bir çember çizer gibi bir döngüye dahil olan ve o döngüyü başladığı yerde tamamlayan kişinin bu değişim nedeniyle hiç de aynı olmadığını ifade eder. Bu cümlede zaman bitmediği için çemberin yuvarlak olmadığının iddia edilmesi, zamanın yaşanmışlıklar etkisiyle kişiyi ve çevresindekileri değiştirdiğini göstermek için gerçekleştirilmiş işlevsel bir kullanımdır. Cümlenin bütünü aynılık içindeki başkalığı, değişmeme görüntüsü altındaki değişimi imleyen ironik bir anlatıma hizmet eder.

Çember bizi filme adını veren en önemli gösterge olan 'yağmur'a da bağlar. Zira dikkate değer bir nokta filme adını veren yağmurun da döngüsel hareket etmesi, yeryüzü ile gökyüzü arasında çember çizmesidir. Şöyle ki yağmur toprağa düşer, ısı artınca buharlaşan yağmur suyu yeniden gökyüzüne yükselir, hava soğuyunca da tekrar yağmur olarak yeryüzünü ıslatır. Görüldüğü gibi yağmurun hareketi de daireseldir. Söz konusu yağmurun düştüğü topraklarda, ölen kişilerin kanları varsa, toprağa yağmur damlalarıyla beraber ölülerin kanları da karışacak ve yine yağmur damlalarıyla beraber buhar olup gökyüzüne yükselecek, insanların üzerine bu kanlar akacaktır. Yani kan, ölüm, savaş, şiddet yağmur aracılı̆̆ıla somut şekilde bir döngü oluşturacaktır. Daha önemlisi yağmur sularıyla yüklü bulutların bütün dünyayı dolaşması gibi, kanla yüklü bulutlar da farklı coğrafyalara gidecek ve kan, yağmurla beraber dünyanın her yerine dökülecektir. Bu yüzden filmde sıklıkla kırmızı bulutlar seyirciye gösterilir. Kanla dolu kızıl renkli bulutlar dünyanın her yerine yağmur bırakır. Bu nedenle savaş, şiddet ve ölüm bütün dünyayı dolaşacak, her yerde olacaktır. Böylece yağmurun çember gibi dairesel hareketi, filmin bütününde çemberin savaş ve ölümün kısır döngüsünü, her yerde oluşunu simgelediğini çok daha açık gösterir. Bu noktada 'yağmur' anlam bakımından çemberle iş birliği içinde bir gösterge olarak son derece anlamlı hale gelir. 
‘yağmur’ savaş, şiddet ve ölüm

Filmin ilk cümlesi dahi filme adını veren bu gösterge üzerine bizi düşünmeye iter. Filmin başında Kiril yüzüne konan sinekleri uzaklaştırmaya çalışırken görülür. Sinekler Kiril'i rahat bırakmaz çünkü birazdan yağmur yağacaktır. Nitekim Rahip uzakta yağan yağmuru göstererek “yağmur yağıyor, birazdan buraya da gelir” (Manchevski, 1994) der. Filmin sonunda anlaşılır ki bu yağmur Zamira'yı kurtardığı için öldürülen Kiril'in amcası, Zamira'nın babası Alex’in ölüsü üzerine yağan yağmurdur. Hemen ardından odasına giden Kiril Zamira'yı orada bulacaktır. Kısa süre sonra Kiril'e aşık olduğu için Zamira öldürülecek, muhtemelen bu defa yağmur onun ölüsü üzerine yağacaktır. Dolayısıyla filmde ‘yağmurdan önce' birileri ölür, kan dökülür, filmin başlığı dilsel gösterge olarak savaşın, ölümün, şiddetin yani ölüm zamanının geldiğinin habercisidir. Yağmurun birazdan gelecek olması, savaşın ve ölümün gelecek olması demektir. Yağmurdan önce ifadesi gerek başıı gerek zaman olarak bir gösterge biçiminde yorumlandığında ölümün habercisi olma anlamını içerir.

‘yağmurdan önce’, ölüm zamanı

Filmin derin anlamına ulaşmaya çok yakın olunan bu noktada filmdeki anlatıda kişilerin yaşadığı çatışmaların saptanması, betisel düzeyde elde edilen verileri son aşamaya ulaştıracaktır. Çatışmaların ortaya çıkardığı karşıtlıklar bütünsel anlamın kapılarını aralayacaktır. Bu nedenle anlamı oluşturan değişik karşıtlık türleri üzerinde durmak gerekir (Kıran, 2007: 328). Karşıtıkları doğuracak olan çatışmalar kişiler arasında yaşanır. Bu yüzden betisel katmanda bakılması gereken önemli öğelerden biri de kişilerdir. Zira filmde kişilerin konumlanışı ve eylemleri bütün görsel öğelerin, nesnelerin kullanımı ve anlamlarıyla koşuttur. Filmin ana kişileri olan Alex, Zamira ve Kiril'e bakıldığında üçünün de farklı şekillerde savaştan kaçmaya çalıştığı görülür. Zamira başına neyin neden geleceğini bilmeden ve kendini anlatamadan kaçar, Alex savaş olan ülkesinden kaçıp Londra'ya ve sanata sığınmıştır, Kiril ise bu koşullarda en iyi yol olarak konuşmamayı seçmiş, çareyi Tanrı'ya sığınmakta bulmuştur. Yani ana kişiler diğerlerinden ve diğerlerinin sürdürdüğü savaştan kaçar, savaşın sonlanmasını isterler. Ancak üçü de bu kaçış sonucunda kaçtıkları şeyin yani savaş, nefret, ölüm ve şiddetin kucağına düşmüşlerdir. Filmin sonunda sevgiden, yaşamdan, barıştan, huzurdan yana olan bu ana kişiler yenik durumdadır, savaştan kaçamamışlar, savaşı bitirememişler hatta savaşta taraf olmak zorunda kalmışlardır. Onların girdiği ana çatışmalar ve uğradıkları yenilgi, bizi filmin savaşın kaçınılmazlığı ve çaresizlik temelindeki derin anlamına götürecek olan bir dizi karşıtık üretmiştir. Bütün bu karşıtlıklar, karşıt taraflar anlamına gelen 'kt' kısaltmasıyla bir kez daha özetlenebilir.

$\begin{array}{lll}\text { Kiril, Alex, Zamira } & \mathrm{kt} & \text { diḡerleri } \\ \text { Barış } & \mathrm{kt} & \text { savaş } \\ \text { Sevgi } & \mathrm{kt} & \text { nefret } \\ \text { Yaşam } & \mathrm{kt} & \text { ōlūm } \\ \text { Huzur } & \mathrm{kt} & \text { şiddet } \\ \text { Savaşın bitmesi } & \mathrm{kt} & \text { savaşın sonsuzluğu } \\ \text { Savaştan kaçmak } & \mathrm{kt} & \text { savaşta taraf olmak }\end{array}$

\section{2. Derin Yapı}

Greimasçı göstergebilim çözümlemesindeki temel hedef yüzey yapıdan hareketle derin yapıya, anlatıdan hareketle anlama ulaşmak, bunu en doğru şekilde gerçekleştirebilecek bir yöntem kullanmaktır. Bu yöntemde yüzey yapı ve derin yapı birbirinden uzak, ayrı düşünülemez. "İki düzey bir yere kadar birbirinden bağımsız olarak ele alınabilse bile birbirinden bağımsız değildir tam tersine birbirini bütünler" (Yücel, 2005:146). Burada ele alınan film çerçevesinde Greimas göstergebiliminin temel hedefi olan derin yapıdaki anlama ulaşmak ereğine büyük oranda yaklaşılmıştır. Filmin anlatı dizgesinden ve kullanılan betisel öğelerden yola çıkılarak yapılan çözümlemede gelinen bu noktada, filmin alt katmanında yer alan derin anlam yavaş yavaş gün yüzüne çıkmaktadır. Bu anlam net bir şekilde ifade edildiğinde yüzey yapıda öne sürülen tüm saptamalarla bütünlük içinde olduğu görülecektir.

Yüzey yapıda detaylı olarak ele alınan filmin bütününde kurgulanan anlatıya, öykülere, kullanılan tüm göstergelere, kişilerin içinde bulunduğu çatışmalara 
bakıldığında, derin yapıda savaşın kaçınılmazlığı ve çaresizlik temasından ortaya çıkan bir ileti belirginleşir. Her ne kadar bu çok katmanlı anlamı her yönüyle kapsayan bir cümleye ulaşmak zor olsa da, yapılan çözümlemeden hareketle filmin derin yapısında yer alan bütüncül anlam şu cümlelerle özetlenebilir: Ne zaman biri ölse ardından 'yağmur' yağar, 'yağmurdan önce' her zaman kan dökülür. Sonra yağmur yağar, toprağa bulaşan kan temizlenir, kanla yüklü sular 'ağaçlar'ın köklerini yıkar, savaştan kaçan masum insanlar ondan kaçtıkça bir şekilde savaşa dahil olur, 'yağmurdan önce' yine o ağaçların dibinde en yakınlarını öldürür ya da kendileri ölür. Sonra yine yağmur yağar, toprağa bulaşan kan temizlenir, ağaçları sulayan aynı kanla yüklü sular buharlaşıp gökyüzüne ulaşır, kızıl renkli bulutlara dönüşüp dünyanın dört bir yanını dolaşır, bu 'yağmur' gittiği her yere kanı, savaşı, şiddeti, ölümü taşır. Bu yüzden 'yağmur/ savaş birazdan buraya da gelir'. Özetle ne kadar uzakta da olsak yağmur gelir bizi bulur yani bir yerde savaş oluyor, kan akıyor, insanlar ölüyorsa kimse kendini bunun dışında tutamaz. Üstelik bu yağmur öldürenlerin ya da ölüme duyarsız kalanların vicdanını da yıkayıp temizlemez, yalnızca onları bu ölüm döngüsüne dahil eder... Bu döngü hep böyle devam eder ama bu sırada insan da aynı kalmaz değişir. Çünkü 'zaman bitmez, çember asla yuvarlak değildir'. Böylelikle Greimas göstergebiliminin son aşaması olan derin anlama ulaşı lmış, yüzey yapıyla uyum içerisinde bütünleşen derin yapı, yöntemin bu yazıda ele alınan film çerçevesinde hedefini yakaladığını gözler önüne serer.

\section{Sonuç}

Sonuç olarak, Greimas göstergebilim yöntemiyle Yağmurdan Önce filmi analiz edilirken yüzey yapı denilen ilk aşamada filmin içerdiği anlatıdaki tüm eyleyen öznelerin nesnelere kavuşma çabası üç epizot için ayrı ayrı incelenmiş, bu süreçte eylemlerin kişi ve durumlar üzerinde yarattığı dönüşümler Greimas göstergebilimine özgü şema ve kısaltmalarla görselleştirilmiştir. Aynı aşamada filmde yer alan tüm dilsel göstergeler ve görüntüler gösteren ve gösterilen yani kavram ve anlam ilişkisi üzerinden filmin bağlamı içinde yorumlanmış, kişiler ve temsil ettikleri değerler açısından çatışma yaratan tüm karşıtlıklar özetlenmiştir. Derin yapıya geçildiğinde anlatı, dönüşüm, gösterge ve karşıtlıkların açtığı yolda çok yönlü bir anlama ulaşılmış, filmin anlattığı düşünce ya da düşünceler şeffaflık kazanmıştır.

Tüm bu açıklamalardan sonra genel olarak bulgulara bakıldığında Greimas'ın göstergebilim yönteminin öyküden, romana, oyundan, sinema filmine dek uzanan, anlatıya dayalı her tür sanat eserine uygulanabilecek geniş kapsamlı bir yöntem olduğu görülmektedir. İlk bakışta yöntemin yalnız edebiyatla sınırlı sanılmasının aksine çok sinemayı da kapsayan geniş bir yelpazeye yayılabildiği anlaşılmaktadır. Greimasçı göstergebilim, yüzey yapıdan hareketle derin yapıya, görünenden hareketle anlama ulaşmada kolay, işlevsel, tutarlı bir analiz yöntemi somut olarak karşımızda durmaktadır. Yöntem adım adım uygulandığında, hedeflenen anlama net bir şekilde ulaşıldığı gözlemlenmiştir.

Bütün bunların yanında bulgulardan hareketle denilebilir ki, Yağmurdan Önce filmi çok yönlü bir anlam dünyasını izleyiciye sunmaktadır. Filmin derininde yatan bu anlamlar, bu yazıda göstergebilimsel metodun aşamalarının bir bir geçilmesiyle yavaş yavaş aydınlığa kavuşmuştur. Filmde derinde yatan anlam doğrultusunda harekete geçirilen anlatı dizgeleri, öyküler, göstergeler, kişiler ve çatışmalar filmin bağlamı içinde, birbirleriyle ilişkili olarak çözümlendiğinde anlam katmanları bir bir açılmakta, derinde yatan bütüncül anlam bir bilmece gibi açığa çıkmaktadır. Tekrar etmek gerekirse bu bütüncül anlam savaşın yıkıcı etkisi üzerinde yoğunlaşmakta, filmde savaşın kaçınılmaz, yıkıcı, döngüsel bir olgu olduğu çok sarsıcı bir anlatımla sunulmaktadır. Bu yazıda göstergebilimsel yöntem açısından verimli bir örnek niteliği taşıyan bir sinema filmi, uygun bir yöntemle buluşmuş ve ortaya Greimasçı göstergebilimin amacına ulaştığını gösteren tutarlı bir inceleme çıkmıştır.

Greimas'ın göstergebilim yöntemi sayesinde estetik bir seyir zevki sunan, etkileyici ve akıcı bir anlatı barındıran sinema filminin ilk bakışta karmaşık ve çok yönlü görünen anlamındaki bulanıklık yavaş yavaş kaybolmuş, çözümleme sonunda her şey netliğe 
kavuşmuştur. Bu yöntem anlamın taşıyıcısı olan bir sanat eserine nasıl yaklaşılması gerektiği konusunda bilimsel bir yol haritası sunmaktadır. Bu yol haritasına uygun olarak adım adım ilerlemek anlama ulaşmayı kolaylaştırırken okuyucuya/izleyiciye bir yapbozun parçalarını bir araya getirmenin çocuksu, oyunsu hazzını yaşatmaktadır. Her bir aşamada yapılan saptamaların bilimsel verilerle, işaret ve şemalarla gösterilmesi yapılan incelemeye somutluk kazandırmaktadır.

Böylecegelinen son noktada Greimas göstergebiliminin uygulanış biçimi açıklığa kavuşmuş, sanat eserlerine yönelik çağdaş ve güncel bir okuma yöntemi gösterilmiştir. Ayrıca temeli anlatıya dayanan, anlamın sığınağı olan her sanat eserine uygulanabilen Greimas'ın göstergebilim yöntemi sinemaya da uygulanmış, bu yazıda bir film çözümlemesi için göstergebilimin işlevsel bir yöntem ve faydalı bir okuma modeli sunduğu somut bir şekilde anlatıımıştır.

\section{Kaynakça}

Greimas, A. J. \& Courtes, J. (1979). Semiotique Dictionnaire Raissone de la Theorie du Langage, Paris: Hachette.

Greimas, A. J. \& Landowski, E. (1979). Introduction A'l'analyse du Discours en Sciences Sociales, Paris: Hachette.

Guiraud, P. (1999). Anlambilim, çev: B. Vardar, İstanbul: Multilingual Yayınları.

Kıran, A. E. \& Kıran, Z. (2007). Yazınsal Okuma Süreçleri, Ankara: Seçkin Yayıncılı.

Manchevski, M. (1994). Yağmurdan Önce, İngiltere, Fransa, Makedonya Ortak Yapım.

Moran, B. (2006). Edebiyat Kuramları ve Eleştiri, İstanbul: İletişim Yayınları.

Öztokat, N. (2005). Yazınsal Metin Çözümlemesinde Kuramsal Yaklaşımlar, İstanbul: Multilingual Yayınları.

Rıfat, M. (1990). Dilbilim ve Göstergebilimin Çağdaş Kuramları, İstanbul: Düzlem Yayınları.
Rıfat, M. (2005). 20. Yüzyılda Dilbilim ve Göstergebilim Kuramları, İstanbul: Yapı Kredi Yayınları.

Vardar, B. (2001). Dilbilimin Temel Kavram ve İlkeleri, İstanbul: Multilingual Yayınları.

Yücel, T. (2005). Yapısalcılık, İstanbul: Can Yayınları. 